Artikel Penelitian

\title{
Hubungan Tingkat Pengetahuan lbu tentang Penanganan Diare dengan Kejadian Diare pada Balita di Kelurahan Korong Gadang Kecamatan Kuranji Kota Padang
}

\author{
Yessi Arsurya ${ }^{1}$, Eka Agustia Rini ${ }^{2}$, Abdiana $^{3}$
}

\section{Abstrak}

Diare masih merupakan penyebab utama morbiditas dan mortalitas pada balita di dunia. Setiap tahunnya terdapat sekitar 2 milyar kasus diare di dunia dan sekitar 1,9 jutanya adalah kasus balita yang meninggal karena diare. Diare termasuk dalam 10 penyakit terbanyak di kota Padang dan wilayah Kuranji selalu menempati tiga peringkat teratas kejadian diare dalam kurun waktu empat tahun. Tujuan penelitian ini adalah menentukan hubungan antara tingkat pengetahuan ibu tentang penanganan diare dan kejadian diare pada balita di kecamatan Kuranji kelurahan Korong Gadang kota Padang. Penelitian ini merupakan penelitian analitik observasional dengan desain cross sectional yang dilakukan pada 150 orang ibu yang memiliki balita usia 1-5 tahun di Kelurahan Korong Gadang Kecamatan Kuranji Kota Padang. Data primer dikumpulkan dengan wawancara menggunakan kuesioner dan diolah secara komputerisasi. Analisis data meliputi analisis univariat dan bivariat dengan uji chi-square. Hasil analisis univariat menunjukkan bahwa sebagian besar ibu memiliki pengetahuan kurang tentang penanganan diare pada balita. Hasil analisis bivariat menunjukkan ada hubungan antara tingkat pengetahuan ibu tentang penanganan diare dengan kejadian diare pada balita dimana $p$-value $<\alpha(0,042 \leq 0,05)$.

Kata kunci: diare, pengetahuan, balita

\begin{abstract}
Diarrhea is the one of the major causes of morbidity and mortality in children under five worldwide. Each year there is about 2 billion cases of diarrhea in worldwide and about 1,9 million are cases of children under five deaths because of diarrhea. Diarrhea is one of the $10^{\text {th }}$ highest infectious diseases in Padang and Kuranji always be the $3^{\text {rd }}$ ranks incidence of diarrhea for last four years. The objectives of this study was to determine the relationship between mother's level of knowledge about the treatment of diarrhea and the incidence of diarrhea in children under five of Korong Gadang Kuranji Padang. This study is a cross sectional analytic observational conducted on 150 mothers who had children aged 1-5 years in Korong Gadang Kuranji Kota Padang. Primary data was collected by interviews using questionnaires. Data analysis consist of univariate and bivariate with statistical analysis using using chi-square test. Results of univariate analysis showed that most of mother are categorized as low knowledge level. Results of bivariate analysis showed relation between mother's level knowledges about the treatment of diarrhea with the incidence of diarrhea in children under five in which p-value $<\alpha(0,042 \leq 0,05)$.
\end{abstract}

Keywords: diarrhea, knowledge, children under five

Affiliasi penulis: 1. Prodi Profesi Dokter FK Unand (Fakultas Kedokteran Universitas Andalas Padang, 2. Bagian IImu Kesehatan Anak FK Unand 3. Bagian Kesehatan Masyarakat FK Unand Korespondensi: Yessi Arsurya, Email: yessiarsurya@gmail.com, Telp:081364797940

\section{PENDAHULUAN}

Diare masih merupakan masalah kesehatan utama pada anak di dunia. Setiap tahunnya terdapat sekitar 2 milyar kasus diare di dunia dan 1,9 juta anak usia di bawah 5 tahun meninggal karena diare. ${ }^{1}$ Lebih 
dari setengah kematian pada balita yang diakibatkan oleh diare terjadi di negara berkembang seperti India, Nigeria, Afghanistan, Pakistan, dan Ethiopia. ${ }^{2}$ Setiap tahunnya terdapat $25,2 \%$ balita di Indonesia yang meninggal dunia karena diare. ${ }^{3}$

Depkes RI menyatakan bahwa diare merupakan pembunuh balita kedua di Indonesia setelah pneumonia. ${ }^{3}$ Diare berkontribusi sekitar $18 \%$ dari seluruh kematian balita di dunia atau setara dengan lebih dari 5 ribu balita meninggal perhari. ${ }^{4}$ Prevalensi diare di Indonesia sebesar 9\% dan propinsi Sumatera Barat adalah salah satu propinsi yang berada pada prevalensi klinis diare di atas rata-rata sebesar $9,2 \%{ }^{5}$

Menurut data Dinas Kesehatan Kota Padang, diare masih menempati 10 penyakit terbanyak di kota Padang. ${ }^{6}$ Kasus yang terjadi juga mengalami peningkatan berturut-turut, tahun 2009 sebanyak 729 kasus, tahun 2010 sebanyak 911 kasus, dan tahun 2011 sebanyak 1.055 kasus. Berdasarkan data terakhir kejadian diare di Kota Padang tahun 2012, terdapat 8.842 kasus dengan jumlah kasus pada balita sebanyak 2.531 kasus. $^{6}$

Berdasarkan analisis data kejadian diare dari Dinas Kesehatan Kota Padang beberapa tahun terakhir, wilayah Kuranji selalu berada dalam tiga peringkat teratas kasus diare pertahunnya dalam kurun waktu empat tahun terakhir dengan tren kejadian diare yang fluktuatif tiap tahunnya (tahun 2009 sebanyak 355 kasus, 2010 sebanyak 495 kasus, 2011 sebanyak 654 kasus, dan 2012 sebanyak 342 kasus). ${ }^{6}$

Diare termasuk dalam 5 penyakit terbanyak pada balita di puskesmas Kuranji. ${ }^{7}$ Jumlah kasus diare pada balita tahun 2012 di puskesmas Kuranji sebanyak 342 kasus $(17,1 \%)$ dan terbanyak ditemukan di Kelurahan Korong Gadang dengan 221 kasus $(15,5 \%)^{7}$

Diare adalah frekuensi pengeluaran dan kekentalan feses yang tidak normal. ${ }^{8}$ Sedangkan menurut WHO diare adalah buang air besar yang lunak atau cair dengan frekuensi 3 kali atau lebih per hari. $^{9} \quad$ Biasanya merupakan gejala pada gastrointestinal yang dapat disebabkan oleh berbagai agen infeksi seperti bakteri, virus, dan parasit. Infeksi dapat menular dari makanan yang terkontaminasi dan hygiene yang kurang. ${ }^{4}$

Pada umumnya balita yang mengalami diare dapat sembuh sendiri karena $40 \%$ diare disebabkan oleh Rotavirus. ${ }^{8}$ Namun jika tidak dikenali dan ditangani secara dini dapat menyebabkan dehidrasi. ${ }^{10}$ Dehidrasi yang dibiarkan lama-kelamaan akan jatuh dalam keadaan berat hingga menyebabkan kematian. ${ }^{11}$ Berdasarkan penelitian sebelumnya yang dilakukan oleh Kasman tentang faktor risiko diare ditemukan bahwa terdapat hubungan yang signifikan antara pengetahuan ibu $(p=0,001)$ dengan kejadian diare pada balita. ${ }^{12}$

Penelitian ini dilakukan untuk mengetahui hubungan tingkat pengetahuan ibu tentang penanganan diare dengan kejadian diare pada balita di kelurahan Korong Gadang Kecamatan Kuranji kota Padang.

\section{METODE}

Dalam penelitian ini pendekatan yang digunakan adalah penelitian cross sectional, dengan melakukan observasi atau pengumpulan data variabel dependen dan independen hanya satu kali dalam satu saat. Teknik pengambilan sampel dalam penelitian ini adalah menggunakan teknik proportional simple random sampling. Besar jumlah sampel dihitung menggunakan rumus besar sampel. Instrumen yang digunakan dalam penelitian ini melalui kuesioner. ${ }^{13}$

\section{HASIL}

\section{Analisis Univariat}

Analisis ini menggambarkan distribusi frekuensi dari variabel yang diteliti, baik variabel dependen maupun independen yang akan disajikan dalam bentuk tabel distribusi frekuensi.

Tabel 1. Distribusi responden berdasarkan kelompok umur

\begin{tabular}{lcc}
\hline Kelompok Umur Ibu & $\mathbf{f}$ & $\%$ \\
\hline$<32$ tahun & 61 & 40,7 \\
$\geq 32$ tahun & 89 & 59,3 \\
\hline Total & 150 & 100 \\
\hline
\end{tabular}


Berdasarkan Tabel 1 dapat dilihat bahwa sebagian besar ibu balita berumur $\geq 32$ tahun $(59,3 \%)$.

Tabel 2. Distribusi responden berdasarkan tingkat pendidikan

\begin{tabular}{lcc}
\hline Tingkat & $\mathbf{f}$ & $\%$ \\
Pendidikan & & \\
\hline Dasar & 8 & 5,3 \\
Menengah & 142 & 94,7 \\
\hline Total & 150 & 100 \\
\hline
\end{tabular}

Berdasarkan Tabel 2 dapat dilihat bahwa sebagian besar ibu balita berpendidikan menengah $(94,7 \%)$.

Tabel 3. Distribusi responden berdasarkan tingkat pekerjaan

\begin{tabular}{lcc}
\hline Pekerjaan & $\mathbf{f}$ & $\%$ \\
\hline Tidak Bekerja & 101 & 67,3 \\
Bekerja & 49 & 32,7 \\
\hline Total & 150 & 100 \\
\hline
\end{tabular}

Berdasarkan Tabel 3 dapat dilihat bahwa sebagian besar ibu balita tidak bekerja $(67,3 \%)$.

Tabel 4. Frekuensi dan persentase kejadian diare pada balita

\begin{tabular}{lcc}
\hline Kejadian Diare & $\mathbf{f}$ & \% \\
\hline Diare & 95 & 63,3 \\
Tidak Diare & 55 & 36,7 \\
\hline Total & 150 & 100 \\
\hline
\end{tabular}

Berdasarkan Tabel 4 dapat dilihat bahwa sebagian besar balita mengalami diare $(63,3 \%)$.

Tabel 5. Frekuensi dan persentase tingkat pengetahuan ibu tentang penanganan diare pada balita

\begin{tabular}{lcc}
\hline Tingkat & $\mathbf{f}$ & $\%$ \\
Pengetahuan & & \\
\hline Kurang & 105 & 70,0 \\
Baik & 45 & 30,0 \\
Total & 150 & 100 \\
\hline
\end{tabular}

Berdasarkan Tabel 5 dapat dilihat bahwa sebagian besar ibu memiliki tingkat pengetahuan kurang $(70,0 \%)$.

\section{Analisis Bivariat}

Analisis ini digunakan untuk melihat apakah terdapat hubungan antara tingkat pengetahuan ibu tentang penanganan diare dengan kejadian diare pada balita. Analisis yang digunakan adalah uji chi-square dengan derajat kemaknaan $p \leq 0,05$.

Tabel 6. Hubungan tingkat pengetahuan ibu tentang penanganan diare dengan kejadian diare pada balita

\begin{tabular}{|c|c|c|c|c|}
\hline \multirow{2}{*}{$\begin{array}{l}\text { Tingkat } \\
\text { Pengetahuan } \\
\text { Ibu }\end{array}$} & \multicolumn{2}{|c|}{ Kejadian Diare } & \multirow[b]{2}{*}{ Total } & \multirow[b]{2}{*}{$\mathbf{p}$} \\
\hline & Diare & $\begin{array}{l}\text { Tidak } \\
\text { Diare }\end{array}$ & & \\
\hline Kurang & 72 & 33 & 105 & 0,042 \\
\hline Baik & 23 & 22 & 45 & \\
\hline Total & 95 & 55 & 150 & \\
\hline
\end{tabular}

Berdasarkan Tabel 6 dapat dilihat bahwa dari 105 orang ibu yang memiliki tingkat pengetahuan kurang, sebanyak 72 orang $(68,6 \%)$ balitanya pernah mengalami diare, dan 33 balita $(31,4 \%)$ tidak terkena diare. Dari 45 orang ibu yang memiliki tingkat pengetahuan baik, sebanyak 23 orang $(51,1 \%)$ balitanya pernah mengalami diare dan 22 balita $(48,9 \%)$ tidak terkena diare.

Hasil uji statistik dengan uji chi-square ditemukan ada hubungan antara tingkat pengetahuan ibu tentang penanganan diare dengan kejadian diare pada balita dimana $p<\alpha(0,042 \leq 0,05)$.

\section{PEMBAHASAN}

Karakteristik ibu balita dalam penelitian ini mencakup umur ibu, tingkat pendidikan, dan pekerjaan. Mayoritas ibu berumur $\geq 32$ tahun, berpendidikan menengah (mayoritas SLTA/ sederajat), dan tidak bekerja (ibu rumah tangga).

Sebagian besar balita mengalami diare $(63,3 \%)$. Angka ini berada di atas angka nasional insidensi diare klinis di Indonesia $(9,0 \%)$ menurut Riskesdas pada tahun $2007 .{ }^{5}$ Tingkat pengetahuan ibu berada dalam kategori kurang (70\%).

Pada penelitian ini didapatkan adanya hubungan antara tingkat pengetahuan ibu tentang penanganan diare dengan kejadian diare pada balita dengan $p \leq 0,05$.

Didapatkan bahwa dari 105 orang ibu yang memiliki tingkat pengetahuan kurang tentang cara 
penanganan diare pada balita, $68,6 \%$ balitanya pernah mengalami diare dan $31,4 \%$ balita lainnya tidak terkena diare. Hal ini menggambarkan bahwa ibu yang memiliki pengetahuan kurang ternyata cukup banyak balitanya yang mengalami diare dalam satu bulan terakhir. Ibu yang memiliki pengetahuan baik tentang penanganan diare pada balita ternyata juga tidak jauh berbeda proporsinya antara balita yang pernah terkena diare $(51,1 \%)$ dan tidak terkena diare $(48,9 \%)$.

Secara statistik, uji chi-square yang telah dilakukan menunjukkan ada hubungan yang bermakna antara tingkat pengetahuan ibu tentang penanganan diare dengan kejadian diare pada balita, dimana didapatkan nilai $p=0,042(p \leq 0,05)$. Hal ini sejalan dengan penelitian yang dilakukan oleh Kasman (2004) yang mendapatkan bahwa ada hubungan yang signifikan antara pengetahuan ibu $(p=0,001)$ dengan kejadian diare pada balita. ${ }^{12}$ Hasil penelitian ini juga sejalan dengan penelitian yang dilakukan oleh Herwindasari tahun 2014 yang meneliti tentang Hubungan Tingkat Pengetahuan lbu dengan Penatalaksanaan Awal Diare pada Balita. Didapatkan adanya hubungan antara tingkat pengetahuan ibu dengan penatalaksanaan awal diare pada balita $(p=$ $0,017) .^{14}$

Pada penelitian ini dapat dilihat bahwa tingkat pengetahuan ibu yang kurang tentang penanganan diare menjadi salah satu faktor risiko terjadinya diare $(\mathrm{RP}=2,087$ dan $\mathrm{Cl}=1,021-4,267)$. Artinya, balita yang ibunya memiliki tingkat pengetahuan kurang kemungkinan berisiko balitanya mengalami diare 2 kali lebih besar dibandingkan balita yang ibunya memiliki tingkat pengetahuan baik.

Jika dibandingkan proporsi balita yang mengalami diare didapatkan hasil yang tidak jauh berbeda antara balita yang ibunya memiliki tingkat pengetahuan kurang $(68,6 \%)$ dengan balita yang ibunya memiliki tingkat pengetahuan baik $(51,1 \%)$ tentang penanganan diare. Hal ini terjadi karena kejadian diare tidak hanya disebabkan oleh tingkat pengetahuan ibu saja tetapi juga oleh karena faktor lain seperti: sumber air minum yang tidak bersih, hygiene dan sanitasi lingkungan, gizi balita, dan lainnya. Faktor-faktor tersebut dapat menyebabkan kejadian diare tanpa berpengaruh pada tingkat pengetahuan ibu balita.
Sanitasi lingkungan merupakan salah satu faktor yang mempengaruhi kejadian diare. ${ }^{15}$ Ketersediaan jamban yang bersih dan layak serta ketersediaan air bersih di rumah. Ketersediaan jamban yang tidak sehat, pembuangan $B A B$ yang tidak pada tempatnya dapat mencemari sumber air minum dan dapat menjadi media penularan diare. DAS Kuranji yang berada di wilayah penelitian yang dalam observasi peneliti masih digunakan oleh warga setempat untuk MCK turut memicu tingginya angka kejadian diare pada balita.

\section{SIMPULAN}

Berdasarkan hasil penelitian dan pembahasan, disimpulkan bahwa ada hubungan antara tingkat pengetahuan ibu tentang penanganan diare dengan kejadian diare pada balita, dengan nilai $p=0,042$.

\section{UCAPAN TERIMA KASIH}

Terima kasih kepada semua pihak atas bimbingan, arahan dan motivasi dalam penyelesaian penelitian ini.

\section{DAFTAR PUSTAKA}

1. Farthing M, Salam M, Lindberg G, Dite P, Khalif I, Salazar-Lindo E, Ramakrishna BS, Goh K, Thomson A, Khan AG, Krabshuis J, LeMair A. Acute Diarrhea in adults and children: a global perspective. Australia: World Gastroenterology Organisation Global Guideline; 2012.

2. UNICEF. Pneumonia and diarrhoea: tackling the deadliest diseases for the world's poorest children. 2012 (diunduh 23 Juli 2013). Tersedia dari: URL: HYPERLINK http://www.unicef.org/

3. Kemenkes RI. Profil data kesehatan Indonesia tahun 2011. Jakarta: Kemenkes RI; 2011.

4. WHO/UNICEF Joint statement. clinical management of acute diarrhea. 2004 (diunduh 20 Juli 2012). Tersedia dari: URL: HYPERLINK http://www.who.int/.

5. Kementerian Kesehatan RI. Laporan hasil riset kesehatan dasar (Riskesdas). Badan Penelitian dan Pengembangan Kesehatan Kementerian Kesehatan RI; 2007. 
6. Dinas Kesehatan Kota Padang. Profil kesehatan Kota Padang tahun 2012. Padang: DKK Padang; 2013.

7. Puskesmas Kuranji. Cakupan kasus diare tahun 2012. Padang: Puskesmas Kuranji; 2012.

8. Dorland WAN. Kamus kedokteran Dorland. Edisi ke-29. H Hartanto, penterjemah. Jakarta: EGC; 2002.

9. World Health Organization (WHO). Pelayanan kesehatan anak di rumah sakit. Tim Adaptasi Indonesia, Diare Akut. Jakarta: WHO Indonesia; 2009.

10. Forfar, Arneils. Textbook of pediatrics. Edisi ke-6. British: Churchill Livingstone; 2003.

11. UNICEF. Diarrhoea: why children are still dying and what can be done. 2009 (diunduh 23 Juli 2013). Tersedia dari: URL: HYPERLINK http://www.unicef.org/.
12. Kasman. Faktor-faktor yang berhubungan dengan kejadian diare pada balita di Puskesmas Air Dingin Kecamatan Koto Tangah Kota Padang Sumatera Barat Tahun 2003 (skripsi). Medan: Universitas Sumatera Utara; 2004.

13. Sastroasmoro S, Ismael S. Dasar-dasar metodologi penelitian klinis. Jakarta: Sagung Seto; 2002.

14. Herwindasari E. Hubungan tingkat pengetahuan ibu dengan penatalaksanaan awal diare pada balita di wilayah kerja Puskesmas Perumnas II Pontianak Tahun 2013 (skripsi). Pontianak: Universitas Tanjungpura; 2014.

15. Adisasmito W. Faktor risiko diare pada bayi dan balita di Indonesia: systematic review penelitian akademik bidang kesehatan masyarakat. Makara Kesehatan. 2007;11: 1. 